\title{
Entomophagy: A Future Feed Security System
}

\author{
Avisikta Ghosh Dastidar ${ }^{1} \mid$ Swagatalakshmi Chakraborty ${ }^{1}$ | Dolanchapa Sikdar ${ }^{1}$ | Rosalin Nath $^{1}$ \\ ${ }^{1}$ Department of Food Technology, Guru Nanak Institute of Technology, Kolkata, India
}

To Cite this Article

Avisikta Ghosh Dastidar, Swagatalakshmi Chakraborty, Dolanchapa Sikdar and Rosalin Nath, "Entomophagy: A Future Feed Security System", International Journal for Modern Trends in Science and Technology, 6(12): 301-309, 2020.

\section{Article Info}

Received on 10-November-2020, Revised on 02-December-2020, Accepted on 06-December-2020, Published on 14-December-2020.

\section{ABSTRACT}

From the point of view of the current environmental situation which leads to non-availability of agricultural land, water resource, emission of greenhouse gases ultimately causing global warming, Entomophagy i.e. practice of eating edible insects comes as a rescue to the future feed security system. Edible insects, considered as an inexhaustible natural resource have larger food value with high content of fat, protein, crude fiber, vitamins and minerals making it nutritionally comparable with other protein sources. Some edible insects also have increased levels of omega-6 \& 3 fatty acids. Studies have calculated that livestock rearing leads to about $18 \%$ greenhouse gas emission whereas barring a few insects like cockroaches, termites which produce small amount of $\mathrm{CH}$, others have practically no such harmful environmental impact. Socio- economic picture of edible insect trade comes clearly from South-East Asia with its well-established farms and trade routes. The market value for insects often exceeds from that of its other protein counterparts, as a result of which, insect farming can prove to be a rich source of income for farmers. Insect rearing requires very little technical knowledge and principal investment, so it can be taken on by anyone. In future, as prices of conventional protein rises, insects may well prove to be a cheaper source. Here in this review paper, Insect's contribution to food security, solution to the problem of protein shortages, recent growth in demand for edible insects, consumer awareness and acceptance of insects as food has been discussed.

KEYWORDS: Entomophagy, edible insects, protein counterpart, insect rearing, natural resource.

\section{INTRODUCTION}

In many $3^{\text {rd }}$ world countries like India children aresusceptibletomalnutritionduetohighdemandofp rotein- based food leading to its non-availability and hike in price. Day by day scarcity of food resources is increasing and importing of foods is becoming more expensive. Children are being exposed to poor nutritional levels when both macro \& micro nutrients are insufficient to maintain growth and development. To effectively respond to this situation researchers have turned their attention to insects not only because of their abundance and enormous biomass but also because of insects being a source of good quality protein with high digestibility. Thus, wider adoption of entomophagy, practice of eating edible insects could help alleviate growing pressure on food production and also reduce malnutrition. Natural resources like land, water and energy are declining, so these resources need to be conserved and managed to produce more food. Livestock farming is becoming costly progressively. Insect culture, on the other hand, requires little areas, little water and hence is nick named as "mini-livestock". Insects also play an important role in improving soil fertility, breaking down waste products until it is fit to be consumed by bacteria and fungi. Thus, insects are of valuable importance 
medically, commercially, and ecologically. In a world where providing adequate nutrition to people is a huge problem, edible insects should be taken into consideration. The local "conventional" practices of consuming insects are not new (McGrew, 2014). The recent global interest on entomophagy has annexed a new dimension to the concept. 73 out of 98 known companies to proffer insects as animal feed or human food were founded during 2013-2015(Dossey et al., in press). So, definitely a global edible insect 'movement' is coming forth. The benefits of insects as food do not just rely on technical and economic feasibility, but also on political and social context. With the growing world population, there are now more than 3.7 billion people suffering from malnutrition, mainly due to lack of protein and energy from food(Olaf $\mathrm{M}$ et al.,2005). Also, new agricultural land is very little to produce food for human beings, and as such a greater proportion of people are eating resource-intensive animal protein than ever before. This narrative review thus aims to showcase some of the positive $\&$ negative aspects of entomophagy thereby presenting it as a future feed security system. The paper will scrutinize the nutritional benefits, environmental issues, socio economic aspect, disadvantages, food safety \& preservation and future prospects ofentomophagy.

\section{NUTRITIONAL BENEFITS}

Insects are a good source of protein, fat, minerals, vitamins \& energy (Rumpold \& Schlüter 2013a) with comparable energy content with other fresh meat sources which vary across insect species \& within species depending on what they have fed on, their stage of development, sex and environmental factors (Bukkens 1997; Ramos-E lorduy et al. 2002; Finke \& Oonincx 2014).

\subsection{Macro Nutrients}

Protein comprises of about $30 \%$ to $65 \%$ total dry matter, thereby being one of the most important component of edible insects. Amino acid composition and digestibility of protein expressed as a percentage of that of an "ideal" protein is used to check the protein quality (Belluco et al. 2013). Edible insects offer alimited amount of tryptophan \& lysine. Whether insect protein is suitable for human sustenance is yet to be assessed, but studies with juvenile rats have put forward that crickets have superior source of protein when compared to a plant based protein source like soy protein. Insects contain unsaturated fatty acid similar to that of poultry and white fish but more polyunsaturated fatty acid (PUFAs) than poultry or red meat. The main PUFAs which are present in insects are Omega-3 fatty acids, Docosahexanoic acid \& Eicosapentanoic acid andtheyareresponsiblefornormalcellularfunctio ninthehuman body.

\subsection{Micro Nutrients}

Insects have varied level ofmicronutrients which differs from one species to the other, although some have consistently higher values of some specific micronutrients. In some insect species iron is found in the range of 18 to 1562 $\mathrm{mg} / 100 \mathrm{gm}$ dry matter with low levels in ants, mid-levels in termites and the highest levels in cricket (Christensen 2006). Zinc, calcium and vitamin $\mathrm{A}$ are also found in insects. In crickets zinc content is in the range of $8-25 \mathrm{mg} / 100 \mathrm{gm}$ dry matter (Christensen 2006) whereas ants, termites and crickets have calcium in the range of $33-341 \mathrm{mg} / 100 \mathrm{gm}$ dry matter. Vitamin A is present across different species of insects in the range of 3-273 $\mu \mathrm{g} / 100 \mathrm{gm}$ dry matter (Christensen2006).

\begin{tabular}{|c|c|c|c|}
\hline & $\begin{array}{l}\text { Protein } \\
\text { (\% dry } \\
\text { matter) }\end{array}$ & $\begin{array}{l}\text { Fat (\% dry } \\
\text { matter) }\end{array}$ & $\begin{array}{l}\text { Energy } \\
\text { (kcal/100 g) }\end{array}$ \\
\hline $\begin{array}{l}\text { Coleoptera (adult beetles, } \\
\text { larvae) }\end{array}$ & 40.69 & 33.4 & 4903 \\
\hline $\begin{array}{l}\text { Rhynchophorus phoenicis } \\
\text { (palm weevil larvae) }\end{array}$ & 3286 & 36.86 & 47887 \\
\hline $\begin{array}{l}\text { Tenebrio moltor (mealworm } \\
\text { lavae) }\end{array}$ & 4835 & 3851 & 557.12 \\
\hline Diptera (flies) & 49.48 & 2275 & 40978 \\
\hline Hemiptera (true bugs) & 4833 & 30.26 & 47899 \\
\hline Hymenoptera (ants, bees) & 46.47 & 2509 & 484.45 \\
\hline $\begin{array}{l}\text { Oecophyla smaragedina } \\
\text { (weaver ant) }\end{array}$ & 53.46 & 13.46 & \\
\hline Isoptera (termites) & 35.34 & 3274 & \\
\hline Lepidoptera (butterflies, moths) & 45.38 & 27.66 & 50889 \\
\hline Bombyx mori (silloworm larvae) & 61.8 & 8.81 & 3896 \\
\hline Girna forda (shea caterpilar) & 47.48 & 115 & 359 \\
\hline $\begin{array}{l}\text { Galeria mellbnela } \\
\text { (warworm larvae) }\end{array}$ & 3801 & 56.65 & 650.13 \\
\hline $\begin{array}{l}\text { Sarria cyrthia ricini (allanthus } \\
\text { sikworm pupae) }\end{array}$ & 547 & 25.6 & 46363 \\
\hline Odonata (dragonflies, damselflies) & 55.23 & 19.83 & 43133 \\
\hline $\begin{array}{l}\text { Orthoptera (crickets, } \\
\text { grasshoppers, locusts) }\end{array}$ & 61.23 & 13.41 & 42625 \\
\hline $\begin{array}{l}\text { Acheta domestials } \\
\text { (house cricket adult) }\end{array}$ & 65.04 & 2296 & 455.19 \\
\hline Schistocerca sp. & 61.05 & 17 & 427 \\
\hline $\begin{array}{l}\text { Sphenarium purpuracers } \\
\text { (chapulin adult) }\end{array}$ & 61.33 & 11.7 & 40422 \\
\hline Rispolia differens (brown longhorn & 443 & 462 & \\
\hline
\end{tabular}

Table 1:Protein,fatandenergycontentofsomeinsects. Data from Rumpold \& Schlüter2013a. 


\begin{tabular}{|c|c|c|c|}
\hline Species & Calcium & Iron & Vitamin A \\
\hline $\begin{array}{l}\text { Rhynchophorus phoenicis (African } \\
\text { palm weevil lavae) }\end{array}$ & 131.05 & 2275 & 1125 \\
\hline Tenebrio molitor (mealworm lanae) & 45.77 & 5.46 & \\
\hline $\begin{array}{l}\text { Oecophylla smaragdina } \\
\text { (weaver ant) }\end{array}$ & 63.85 & 65.4 & \\
\hline Agro (termites) & 132 & 161 & \\
\hline Bombyx moni (silkwom lavae) & 10231 & 954 & 273.99 \\
\hline $\begin{array}{l}\text { Girina forda Westwood (shea } \\
\text { caterpilar) }\end{array}$ & 17.48 & 2393 & 299 \\
\hline Galleria mellonella (waxworm larvae) & 59.28 & 657 & 4.5 \\
\hline Samia ricini (s'kworm pupae) & 722 & 237 & \\
\hline Acheta domesticus (house cridet adult) & 171.07 & 875 & 24.33 \\
\hline Sphenoium purpuracens (chapulin adult) & 112 & 18 & \\
\hline $\begin{array}{l}\text { Ruspolia differens (brown longhom } \\
\text { grasshopper) }\end{array}$ & 245 & 13 & 280 \\
\hline
\end{tabular}

Table 2: Mineral and Vitamin A content in popularly consumed species. All minerals in $\mathrm{mg} / 100 \mathrm{gm}$ dry matter except Vitamin A ( $\mu \mathrm{g} / 100 \mathrm{gm}$ dry matter). Data from Rumpold \& Schlüter (2013a).

\section{ENVIRONMENTAL CONSIDERATIONS}

Production of food has wider impact on environment which is being brought to the forefront particularly regarding the emissionofgreenhousegaseslikeCO2.Itispredicted thatby

2025 , atleast 1.8 millionpeoplewillbelivinginregions with

inadequatefreshwatersuppliesandafurthertwo-thi rdsofthe global population will be in areas under pressure from dwindling water resources (FAO 2012). Freshwater is a limited resource, out of which an approximate $70 \%$ isused by agriculture and livestock industries (Doreau et al. 2012). Incaseofagriculture, waterisbeingusedinitsdirectfr om\& ultimately to cultivate fodder for the production of livestock. Raiseindemandformeatamplifiesthestrainonprod ucersto

farmextralivestock, whichagainrequiresfurtherlan d. Since insects rely on their environment to control metabolic processes, they are significantly more efficient than other livestock in terms of feed conversion (van Huis 2013). The agricultural sector contributes most of the greenhouse gas emissions, with livestock accounting for an overall $18 \%$ of $\mathrm{CO} 2$ equivalents (van Huis 2013; Sachs 2015). Studies have proven that insects produce much fewer greenhouse gases than standard large livestock and are approximately on par with chickens on a per kilogrambasis.

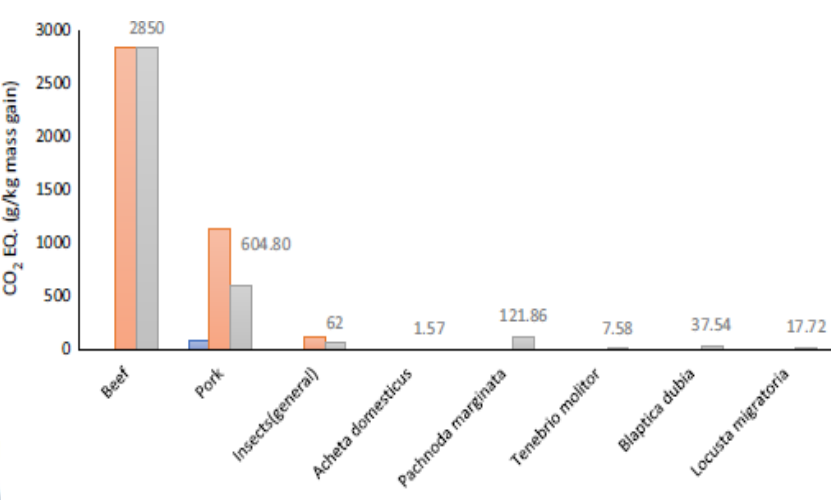

Figure 1: Carbon dioxide (CO2) production equivalents (EQ.) duringrearingoflivestockandinsects.DatafromOonin cxet al. (2010).

\section{SOCIO ECONOMIC ASPECT}

Farming insects can offer unique employment and income earning opportunities in both developed \& developing countries. Insect cultivation can serve as a livelihood diversification strategy that provides multiple income generating means. The market strategies include insects as exoticfood,westernapproachestoday:insectasnove ltyfood and lastly insect as pet food. The benefits of creating such organizations include reduction in the costs of buying farm inputs, production, processingandmarketing. Thea cceptance towards entomophagy comes from increase in price of fresh meat sources, staples \& consumerawareness.

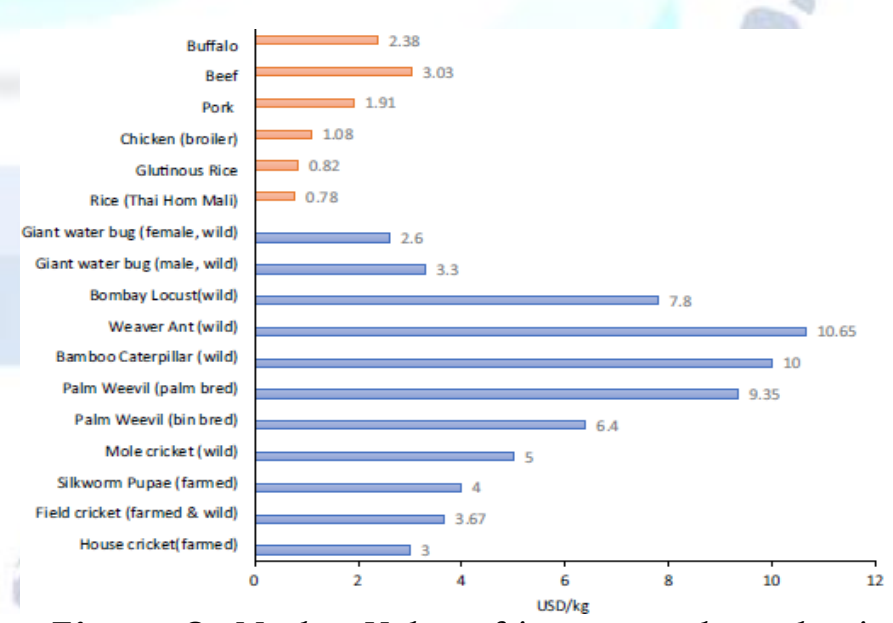

Figure 2: Market Value of insects and staples in Thailand. Insect data from Hanboonsong et al. (2013), rice pricesfromThaiExportersAssociationon2March201 6and meat prices from Thai Office of Agricultural Economics, values for the week of 22 February 2016. 


\section{THE HURDLES NEEDED TO FACE TOUSE INSECTS AS FEED ORFOOD}

Aswealreadyknow, amultitudeofnewopportunitiesli esfor

allowingtheinsectstobeusedasfoodandfeed, therear ealso many hurdles that one has to face to do so, and that is owing to the fact that there are scope for numerous innovative ideas that can employed on entomophagy and also the fact that there has been not enough research done on the subject, thus allowing it to be sceptical for many. The most important of the issues will have to be the distrust over using insects as food as many believe they may contain "anti-nutrient" properties, the apprehensions around food safety associated to storage space and allergic reactions, acceptance by the consumers and vague or unrealparameters.

5.1. Anti-nutrient properties: Chitin is a structural nitrogen- based carbohydrate which is found in the exoskeleton of insects. They may contain "anti-nutrient" properties which can be due to adverse effects on protein digestibility. One studyofseveninsectspeciesfound2.7-49.8mgchitin perkg fresh weight and $11.6-137.2 \mathrm{mg} / \mathrm{kg}$ in dry matter (Finke 2007). And there was also a study which compared dried honeybeesand honeybeeproteinanditendeditsconclusion on the note that chitin exclusion considerably enhanced the quality of the insect protein as considered through protein digestibility, amino acid content, protein efficiency ratio and net protein utilization (Ozimek et al. 1985). Even though chitin is typically considered to be indigestible by humans (Bukkens 1997), thechitinolyticenzymes,formedbyb acteria from the human gastrointestinal tracts, have lately been established, signifying that chitin and chitosan may be digested(Paoletti et al. 2007; Duskova et al. 2011; Rumpold \&Schlüter2013a).Theprobabletoxicityofsomecomp ounds in insects is concerning. Now, there are two categories of toxic insects: phanerotoxics and crypto toxics. Crypto toxics include toxic substances from whichever direct synthesis or by build-up from their diet whereas Phanerotoxics have precise organs that produce toxins (Belluco 2013). Generally consumed insect species are not in this categories, or studies of the levels of oxalate, hydro cyanide, phytate, tannins and phenols in edibles insect species have seen that values fall very well below levels of toxicity for consumption of human (Ekop et al. 2010; Shantibala \& Lokeshwari2014).
5.2. Microbial risks: Spore-forming bacteria and enterobacteriaceae have been reported to be found in mealwormsandcrickets, withelevatedlevelsfoundin insects that had already been crushed possiblydue to the discharge of bacteria from the gut (Klunder 2012). While detrimental bacteria such as Salmonella have been found in insects that were closely in contact with livestock (Belluco 2013), research suggests that gut micro biota of the insects provide for bulk contamination (Rumpold 2014). Some danger of mycotoxins has been recognized, but this has been studied only in the two emperor moth species (Imbrasia belinaand Bucnaea alcinoe), with strains acknowledged chiefly in the intestinal tract or from exterior contamination (Simpanya \& Allotey 2000; Braide \& Oranusi 2011). Very little is known when it comes to the question that howto safely store insects to decrease microbialmenace.

5.3. Allergens: Many arthropods, which include arachnids,

myriapods, crustaceansandinsects,areknowntobri ngabout allergic reactions in predisposed individuals, which are caused by the presence of arginine kinase, tropomyosin, haemocyanin and glyceraldehyde 3-phosphate dehydrogenase (Belluco 2013; Srinroch 2015). Cross- reactive allergies have been identified in cockroaches, dust mites andcrustaceans.

\section{4 .}

Massproduction: Forinsectstobeconsideredfeasib lemicro livestock, it has to be possible to produce them on a hefty scale in a safe, sustainable and efficient way. Noteworthy advances have been made with controlled conditions and artificial rearing diets for mass rearing. The idyllic insect species would have high egg hatch, high egg production, optimum synchronization of pupation, a short larval stage, a highproductivity(i.e.highconversionrateandhighp otential

ofbiomassincreaseperday), highweightsoflarvaeor pupae, low vulnerability to diseases, low feed costs, a high-quality protein content and capability to live in high densities (Rumpold \& Schlüter2013b). 


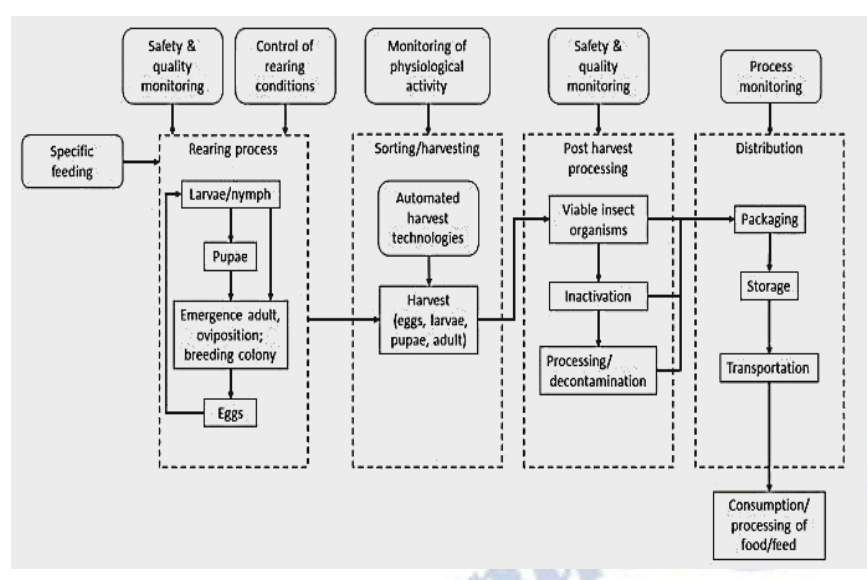

Figure 3: Model insect production system, reproduced from Rumpold \& Schlüter(2013b).

5.5. Consumer acceptability: In countries where entomophagy

isthestandard,insectsareseenasanesteemedprotei nsource and knowledge on which species are edible is considered to be local wisdom which has been passed down through generations. On the contrary, insects can bring into play primeval harmful reactions: 'deeply embedded in the psyche

isaviewofinsectsasdirty, disgustinganddangerous'( Looy et al. 2014). Moderately, the chief significant factors seem to be familiarity, convenience, attachment to meat (Verbeke 2015; Gere 2017) and interest in the environment. Conceivably the first step to escalating consumer acceptability of entomophagy is through improved use in animal feed.

\section{FOOD SAFETY ANDPRESERVATION}

Food safety, preservation and processing are intimately linked. Insects, akin to several meat products, are loaded in moistureandnutrients, providinganencouragingat mosphere for microbial survival and augmentation (Klunder et al., 2012).TheHazardAnalysisCriticalControlPoints(HA $\mathrm{CCP}$ ) system, a science-based and methodical tool, finds out accurate hazards and makes control systems to guarantee the safety of food (FAO/WHO,2001a).

Insects can be conserved and traded after (sun-) drying - a classic method used in processing the mopane caterpillar (Allotey and Mpuchane, 2003). Other effortless preservation methodssuchasacidifyingtheinsectswithvinegarha vebeen triumphant. A different example is the use of insects for protein fortification in fermented food products. A horde of other modern-day preservation methods should be explored, such as the purpose of ultraviolet light and high-pressure technologies, as well as ample packagingmethods.

\section{FUTURE PROSPECTS ANDCONCLUSION}

Future research should deal with questions allied to the levelling up of insect production to industrial levels, such as: how can the environmental trail of insects linger diminutive when levelled up commercially?; how can insect dietetic profiles be enhanced in an organized and reliable conduct?; are there any detrimental effects to human or animal populations from the using up of huge quantities of insects?; howcaninsectsbefedonamercantiledegreeinasustai nable means?; what do the rules around insect farming, processing and storage space necessitate to envelop?; how can the economic assessment of reputable insect supply chains be secluded so as not to injure livelihoods? And what do insect supplyandvaluechainslooklikeaccordingtothepreci seend exercises? Finally, only if insects are capable to contribute with established Western livestock, predominantly chickens, or livestock feed within the supply-value string, will they be deemed a workablesubstitute?

Research points out that insect could play a vital part in managing the looming protein supply predicament. By and large, insects include adequate levels of fats, protein and micronutrients to have a say to advances in universal health and food precautions, mutually by means of straight use and meandering apply in feeds. In accumulation, research has verified that insects can have a trifling environmental trace and a superior monetary significance than other livestock protein sources; they are not likely to cause considerable microbial risks; they have been shown to reason allergic reactions in persons with acknowledged arthropod allergies.

\section{ACKNOWLEDGEMENT}

The Authors acknowledge their sincere thanks to Prof. (Dr.) Kakali Bandyopadhyay, Guru Nanak Institute ofTechnology for guidance and help in writing this reviewpaper. 


\section{REFERENCES}

1. Amadi E \& Kiin-Kabari D (2016) Nutritional composition and microbiology of some edible insects commonly eaten in Africa,hurdlesandfutureprospects:acriticalreview.Jour nal of Food: Microbiology, Safety \& Hygiene 1:1-7.

2. Anvo M, Toguyen A \& Otchoumou A (2016) Nutritional qualities of edible caterpillars Cirina butyrospermi in southwestern of Burkina Faso. International Journal of Innovation and Applied Studies 18: 639.

3. Barsics F, Megido RC \& Brostaux Y (2017) could new information influence attitudes to foods supplemented with edible insects? British Food 119: 2027-39.

4. Belluco S, Losasso C, Maggioletti M et al. (2013) Edible insects in a food safety and nutritional perspective: a critical review. Comprehensive Reviews in Food Science and Food Safety 12: 296-313.

5. Belluco S, Halloran A \& Ricci A (2017) new proteinsources and food legislation: the case of edible insects and EU law. Food Security 9: 803-14. Braide W $\& \quad$ Oranusi S Microbiologicalqualityofanediblecaterpillarofanemperor moth, Bunaea alcinoe. Journal of Ecology and the Natural Environment 3:176-80.

6. Bukkens SGF (1997) the nutritional value of edible insects. Ecology of Food and Nutrition 36: 287-319. Calder P(2017) Omega-3: the good oil. Nutrition Bulletin 42:132-40.

7. Christensen DL, Orech FO, Mungai MN et al. (2006) Entomophagy among the Luo of Kenya: a potential mineral source? International Journal of Food Sciences and Nutrition 57: 198-203. De Goede D, Erens J \& Kapsomenou E (2013) large scale insect rearing and animal welfare. In The Ethics ofConsumption,(HRocklinsberg\&PSandin,Eds)pp.236€ -42. Wageningen Academic Publishers: Wageningen, Netherlands.

8. de Vries M, de Boer IJ (2010) Comparing environmental impacts for livestock products: A review of life cycle assessments. Livestock Science 128: 1-11.

9. DeFoliart G (1992) Insects as human food: gene DeFoliart discusses some nutritional and economic aspects. Crop Protection 11: 395-9. Defoliart GR (1995) Edible insects as mini livestock. Biodiversity and Conservation 4: 306-21.

10. Doreau M, Corson MS \& Wiedemann SG (2012) Water use by livestock: a global perspective for a regional issue? Animal Frontiers 2: 9-16.

11. Durst P \& Hanboonsong Y (2015) Small-scale production of edible insects for enhanced food security and rural livelihoods: experience from Thailand and
Lao People's Democratic Republic. Journal of Insects as Food and Feed 1: 25-31.

12. Ekop E, Udoh A \& Akpan P (2010) Proximate and anti- nutrient composition of four edible insects in Akwa Ibom

State,Nigeria.WorldJournalofAppliedScienceTechnology $2: 224-31$.

13. FAO (Food and Agriculture Organization of the United Nations) (2012) The State of World Fisheries and Aquaculture2012.FoodandAgriculturalOrganizationofth e United Nations: Rome, Italy.

14. FDA (US Food and Drug Administration) (2017) Current Good Manufacturing Practices (CGMPs) - Good ManufacturingPractices(GMPs)forthe2 1stCentury-Food Processing. Center for Food Safety and Applied Nutrition: Silver Spring, Maryland. Finke M (2007) Estimate of chitin in raw whole insects. Zoo Biology 26:105-15.

15. Finke M, Oonincx D (2014) Insects as food for insectivores. In: Mass Production of Beneficial Organisms (JA Morales- Ramos, Rojas MG, DI Shapiro-Ilan Eds), pp. 583-616. Elsevier: Amsterdam, Netherlands.

16.GereA,SzekelyG,KovacsSetal.(2017)Readinesstoadop tinsectsinHungary:acasestudy.FoodQualityandPreferen ce 59: 81-6. Global Market Insights Inc. (2015) Edible Insects Market Size Set to Exceed USD 520 mn by 2023, With Over 40\% Growth From 2016 to2023.

17. Grabowski NT \& Klein G (2016) Microbiology of processed edible insect products - results of a preliminary survey. International Journal of Food Microbiology 243: 103-7.

18. Halloran A, Hanboonsong $Y \&$ Roos N (2017) Life cycle assessment of cricket farming in north-eastern Thailand. Journal of Cleaner Production 156: 83-94.

19. Han S, Lee BS, Jung KJ et al. (2016) Safety assessment of freezedried powdered Tenebrio molitor larvae (yellow mealworm) as novel food source: evaluation of 90-day toxicity in Sprague-Dawley rats. Regulatory Toxicology 77: 206-12.

20.HanR,ShinJF,KimJetal.(2017)AnoverviewoftheSouth Korean edible insect food industry: challenges and future pricing/promotion strategies. Entomological Research 47: 141-51.

21. Hanboonsong Y (2010) Edible insects and associated food habits in Thailand. In: Forest Insects as Food: Humans Bite Back. Proceedings of a workshop on Asia-Pacific resources and their potential for development, 19-21 February 2008, Chiang Mai, Thailand. RAP Publication 2010/02, (PB Durst, DV Johnson, RN Leslie et al. Eds), pp. 173-82. Food and Agriculture Organization of the United Nations: Bangkok, Thailand. 
22. Hanboonsong $Y$, Jamjanya $T \&$ Durst $P B$ (2013)Six-Legged Livestock: Edible Insect Farming, Collecting and Marketing inThailand.FoodandAgricultureOrganizationoftheUnite d Nations: Bangkok, Thailand.

23. Hartmann C \& Siegrist M (2017) Insects as food: perception and acceptance. Findings from current research. Ernahrungs Umschau 64: 44-50.

24. Hoekstra AY (2012) The hidden water resource use behind meat and dairy. Animal Frontiers 2: 3-8. Hoekstra AY \& Mekonnen MM (2012) The water footprint of humanity. ProceedingsoftheNationalAcademyofSciences 109:3232 -7 .

25.

vanHuisA,VanItterbeeckJ,KlunderHetal.(2013)Edible Insects: Future Prospects for Food and Feed Security. Food and Agriculture Organization of the United Nations: Rome, Italy.

26. Hurrell R \& Egli I (2010) Iron bioavailability and dietary reference values. The American Journal of Clinical Nutrition 91: 1461-7.

27.IaconisiV,MaronoS,ParisiGetal.(2017)Dietaryinclusi on of Tenebrio molitor larvae meal: effects on growth performance and final quality treats of blackspot sea bream (Pagellus bogaraveo). Aquaculture 476: 49-58. IPIFF (International Platform Insects for Food \& Feed) (2017) EU Legislation. Available at: www.ipiff.org/our-positions $\quad$ (accessed 8 September2017).

28. Jensen-Jarolim E \& Pali-Scholl I (2015) Caution: reptilepet's shuttle $€$ grasshopper allergy and asthma into homes. World Allergy 8:24.

29. Kelemu S, Niassy S, Torto B et al. (2016) African edible

insectsforfoodandfeed:inventory, diversity,commonaliti es and contribution to food security. Journal of Insects as Food and Feed 1: 103-19.

30. Kinyuru J, Kenji G \& Muhoho S (2011) Nutritionalpotential of longhorn grasshopper (Ruspolia differens) consumed in Siaya District, Kenya. Journal of Agriculture, Science and Technology 12: 1. Klunder HC, Wolkers-Rooijackers J, Korpela JM et al. (2012) Microbiological aspects of processing and storage of edible insects. Food Control 26: 628-31.

31. Koide S (1998) Chitin-chitosan: properties, benefits and

risks.NutritionResearch18:1091-101.Kongkachuichai R\& Napatthalung P (2002) Heme and nonheme iron content of animalproductscommonlyconsumedinThailand.Journ alof Food 15:389-98.
32.L€ahteenm€aki-Uutela A, Grmelova N, Henault-Ethier L et al. (2017) Insects as food and feed: laws of the European Union, United States, Canada, Mexico, Australia, and China. European Food \& Feed Law Review 12: 1.

33. Looy H, Dunkel F \& Wood J (2014) How then shall we eat? Insecteating attitudes and sustainable food ways. Agriculture and Human Values 31:131-41.

34. Loponte R, Nizza S, Bovera F et al. (2017) Growth performance, blood profiles and carcass traits of Barbary partridge (Alectoris barbara) fed two different insect larvae meals (Tenebrio molitor and Hermetiaillucens). Research in Veterinary Science 115:183-8.

35. Lundy ME \& Parrella MP (2015) Crickets are not a free lunch: protein capture from scalable organic side-streams via highdensity populations of Acheta domesticus. PLoS ONE 10: 1-12.

36. Magalh aes R, Sanchez-Lopez A \& Leal R (2017) Black soldier fly (Hermetia illucens) pre-pupae meal as a fish meal replacement in diets for European seabass (Dicentrarchus labrax). Aquaculture 476: 79-85.

37. Makkar HPS, Tran G, Heuze V et al. (2014) State-of-the-art on use of insects as animal feed. Animal Feed Science and Technology 197: 1-33.

38. Marono S, Loponte R, Lombardi P et al. (2017) Productive performance and blood profiles of laying hens fed Hermetia illucens larvae meal as total replacement of soybean meal from 24 to 45 weeks of age. Poultry 96: 1783-90.

39. Megido RC, Gierts C, Blecker C et al. (2016) Consumer acceptance of insect-based alternative meat products in Western countries. Food Quality and Preference 52: 237-43.

40. Megido RC, Desmedt S, Blecker C et al. (2017) Microbiological load of edible insects found in Belgium. Insects 8: 12. Megido RC \& Sablon L (2014) Edible insects' acceptance by Belgian consumers: promising attitude for entomophagy development. Journal of Sensory Studies 29: 14-20.

41. Mekonnen MM \& Hoekstra AY (2010) The green, blue and grey water footprint of crops and derived crop products. Hydrology and Earth Systems Science Discussions 8: 763-809. Mekonnen MM \& Hoekstra AY (2012) A global assessment of the water footprint of farm animal products. Ecosystems 15: 401-15.

42. Miglietta PP, De Leo F, Ruberti M et al. (2015) Mealworms for food: a water footprint perspective. Water 7: 6190-203.

43. Nonaka K (2010) Cultural and commercial roles of edible wasps in Japan. In: Forest Insects as Food: Humans Bite Back. Proceedings of a workshop on 
Asia-Pacific resources and their potential for development, 19-21 February 2008, Chiang Mai, Thailand. RAP Publication 2010/02, (PB Durst, DV Johnson, RN Leslie et al. Eds), p. 123. Food and Agriculture Organization of the United Nations: Bangkok, Thailand.

44.OonincxDGAB\&deBoerIJM(2012)Environmentalimp act of the production of mealworms as a protein source for humans- a life cycleassessment.

45. PLoS One 7: e51145. Oonincx DGAB, van Broekhoven S, van Huis A et al. (2015) Feed conversion, survival and development, and composition of four insect species on diets composed of food by-products. PLoS One 10: e0144601.

46. OonincxDG, vanItterbeeckJ,HeetkampMJetal.(2010 )An exploration on greenhouse gas and ammonia production by insect species suitable for animal or human consumption. PLoS ONE 5:e14445.

47. Ozimek L, Sauer W \& Kozikowski V (1985) Nutritive value

ofproteinextractedfromhoneybees.JournalofFoodScien ce 50:1327-9.

48. Paoletti M \& Dreon A (2005) Minilivestock, environment, sustainability, and local knowledge disappearance. In: Ecological Implications of Minilivestock: Potential of Insects, Rodents, Frogs and Snails, pp. 1-18. CRC Press: Boca Raton, Florida.

49. Paoletti M, Norberto L \& Damini R (2007) Human gastric juice contains chitinase that can degrade chitin. Annals of Nutrition and Metabolism 51: 244-51.

50. Payne CLR, Scarborough P, Rayner M et al. (2016) A systematic review of nutrient composition data available for twelve commercially available edible insects, and comparison with reference values. Trends in Food Science and Technology 47: 69-77.

51. Payne C \& Evans J (2017) Nested houses: domestication dynamics of human-wasp relations in contemporary rural Japan. Journal of Ethno biology and Ethno medicine 13: 13. Piccolo G, Iaconisi V,

52. MaronoSetal.(2017)EffectofTenebriomolitorlarvaem eal on growth performance, in vivo nutrients (C) 2017 The Authors. Nutrition Bulletin published by John Wiley \& Sons Ltd on behalf of British Nutrition Foundation Nutrition Bulletin, 42, 293-308 Edible insects: Opportunities and hurdles 307 digestibility, somatic and marketable indexes of gilthead sea bream (Sparus aurata). Animal Feed Science 226:12-20.

53. Ramos-Elorduy J, Moreno J \& Prado E (1997) Nutritional value of edible insects from the state of Oaxaca, Mexico. Journal of Food Composition and Analysis 10: 142-57.
54. Raubenheimer D \& Rothman JM (2011) Nutritional ecology of entomophagy in humans and other primates. Annual Review of Entomology 58:141-60.

55. Ribeiro JC \& Cunha LM (2017) Allergic risks of consuming edible insects: a systematic review. Molecular Nutrition \& Food Research. https://doi.org/10.1002/mnfr.201700030.

56. Rumpold BA, Frohling A, Reineke K $€$ et al. (2014) Comparison of volumetric and surface decontamination techniques for innovative processing of mealworm larvae (Tenebrio molitor). Innovative Food Science and Emerging Technologies 26: 232-41.

57. Rumpold BA \& Schluter OK (2013a) Nutritional compositionand $€$ safetyaspectsofedibleinsects. Molecular Nutrition and Food Research 57: 802-23.

58.Rumpold BA \& Schluter OK (2013b) Potential and challenges of $€$ insects as aninnovativesourceforfoodandfeedproduction.Innovativ e Food Science and Emerging Technologies 17:1-11.

59. Sachs J (2015) The Age of Sustainable Development. Columbia University Press: New York City, NY.

60.SchiavoneA,CullereM\&DeMarcoM(2017)Partialortot al replacement of soybean oil by black soldier fly larvae (Hermetia illucens L.) fat in broiler diets: effect on growth performances, feed-choice, blood traits. Italian Journal of Animal Science 16:93-100.

61. Shantibala T \& Lokeshwari R (2014) Nutritional and anti-nutritional composition of the five species of aquatic edible insects consumed in Manipur, India. Journal of Insect Science 14: 14.

62. SimpanyaM\&AlloteyJ(2000)Amycologicalinvestigatio $\mathrm{n}$ of phane, an edible caterpillar of an emperor moth, Imbrasia belina. Journal of food protection 63:137-40.

63. Srinroch C, Srisomsap C, Chokchaichamnankit D et al. (2015) Identification of novel allergen in edible insect, Gryllus bimaculatus and its cross-reactivity with Macrobrachium spp. Allergens. Food Chemistry 184: 160-6.

64. St-Hilaire S, Cranfill K \& McGuire M (2007) Fish offal

recyclingbytheblacksoldierflyproducesafoodstuffhighin Omega-3 fatty acids. Journal of the World Aquaculture Society 38:309-13.

65.SuttonM(1995)Archaeologicalaspectsofinsectuse.Jo urnal of Archaeological Method and Theory 2: 253-98. Tan H, Verbaan Y \& Stieger M (2017) How will better products improve the sensory-liking and willingness to buy insect- based foods? Food Research International 92:95-105.

66. Thomas B (2013) Sustainable harvesting and trading of mopane worms (Imbrasia belina) in Northern Namibia: an experience from the Uukwaluudhi area. 
International Journal of Environmental Studies 70: 494-502.

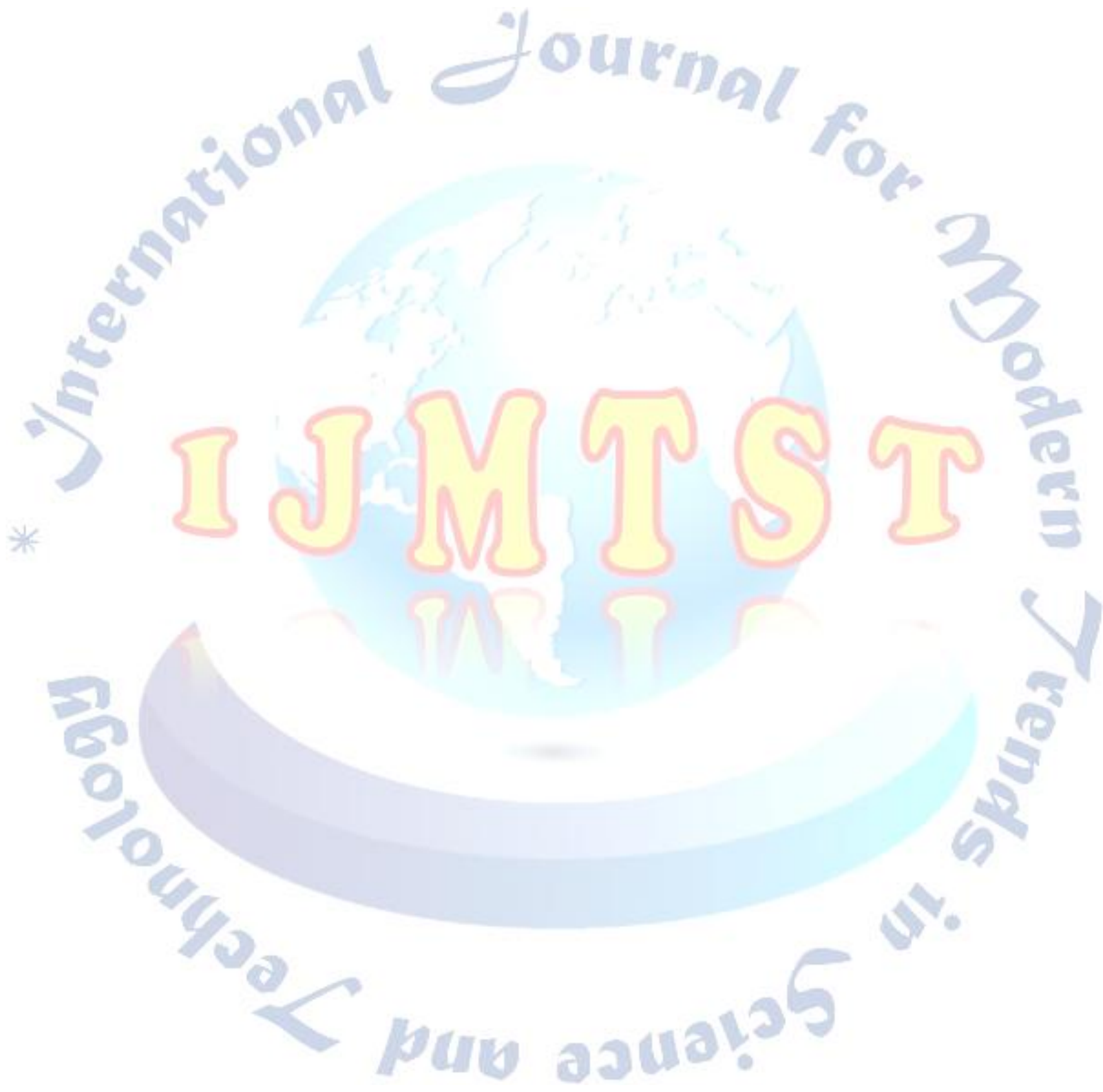

